\title{
Research Productivity in the Human Movement Sciences in the Philippines: A Descriptive Bibliometric and Social Network Analysis
}

\author{
Paula Mae Q. Fernandez ${ }^{1}$, Julius Ceazar G. Tolentino",, ${ }^{1, *}$ John Paul P. Miranda ${ }^{2}$, \\ John Gerald B. Guanlao ${ }^{1}$, Joseph G. Sac ${ }^{1}$ \\ ${ }^{1}$ Department of Physical Education, College of Education, Don Honorio Ventura State University, Pampanga, Philippines
${ }^{2}$ Department of Information Technology, Don Honorio Ventura State University, Mexico Campus, Pampanga, Philippines
}

Received October 16, 2021; Revised January 6, 2022; Accepted January 16, 2022

\section{Cite This Paper in the following Citation Styles}

(a): [1] Paula Mae Q. Fernandez, Julius Ceazar G. Tolentino, John Paul P. Miranda, John Gerald B. Guanlao, Joseph G. Sac, "Research Productivity in the Human Movement Sciences in the Philippines: A Descriptive Bibliometric and Social Network Analysis," International Journal of Human Movement and Sports Sciences, Vol. 10, No. 1, pp. 66 - 78, 2022. DOI: $10.13189 /$ saj.2022.100110.

(b): Paula Mae Q. Fernandez, Julius Ceazar G. Tolentino, John Paul P. Miranda, John Gerald B. Guanlao, Joseph G. Sac (2022). Research Productivity in the Human Movement Sciences in the Philippines: A Descriptive Bibliometric and Social Network Analysis. International Journal of Human Movement and Sports Sciences, 10(1), 66 - 78. DOI: 10.13189/saj.2022.100110.

Copyright $\bigcirc 2022$ by authors, all rights reserved. Authors agree that this article remains permanently open access under the terms of the Creative Commons Attribution License 4.0 International License

\begin{abstract}
The interdisciplinary field of human movement sciences (HMS) has gained massive interest among educational institutions around the world, not only in terms of academic programs but also in research. With this emergence, the researchers aimed to describe the productivity of HMS research in the Philippines. The descriptive bibliometric analysis phase of this paper considered papers published and indexed in Google Scholar from January 2010 to June 2021 and was analyzed after data cleaning and preprocessing. Results revealed that a total of 274 research publications were recorded between the years 2010 and 2021 with an average annual publication rate of $28.6 \%$ as far as the dataset was concerned. Also, public higher education institutions (HEIs) emerged to be the most productive generators of research outputs, specifically topped by the University of the Philippines (UP). Moreover, UP-based authors dominated the rankings of the most productive HMS researchers, with Jeffrey Pagaduan in the top rank. Results further indicated that $75 \%$ of the authors collaborated with fellow researchers within or outside their institution. Meanwhile, the term "physical education" was recorded to be the most frequently appearing word in most of the publications. Through the aid of the data mining approach-
\end{abstract}

social network analysis (SNA), five (5) researchers from public HEIs and two from private HEIs were identified to have the largest networks as discussed in the paper. The exploration of research in terms of productivity and the embedded social network of researchers may serve as a springboard in defining the future development of the field in the Philippines.

Keywords Bibliometric Analysis, Research Publication, Physical Education, Social Network Analysis, University of the Philippines

\section{Introduction}

The production of research outputs in every field has been a perennial practice, not only to prove or generate theories and knowledge but also to promote advances in various areas of specialization toward dissemination and utilization. As a result, the outputs of such research have been progressing and have significantly provided substantial resources in different branches of knowledge. Relatively, Akarowhe [1] defined research as the 
production of new knowledge that can contribute to the improvement of any area of a nation's economy including various professions. It may come up with new and creative ways of understanding issues with the use of existing research.

In the age of ranking systems, the "quantity" of research publications is somehow being stressed rather than the "quality." The fair metric system for incentives, promotion, and employment ranking is commonly involved by the staff's publication quantity [2]. For instance, in the field of education, the number of publications indicates a faculty member's productivity when viewed through a traditional lens [3]. Moreover, Lahiri and Kumar [4] measured and ranked the effectiveness of academic institutions and faculty members based on the number of publications they published in the top international business journals. It may be compared to the "publish or perish" aphorism that counts the number of articles published to thrive in the academic setting [5].

The efficacy of producing research outputs entails a huge indicator of productivity [6]. In research, the term "productivity" pertains to the number of research papers being published [6] [7] [8]. Nygaard [7] defined research productivity as the number of research outputs a faculty member produces, thereby manifesting a quantitative nature as a measure of success. Moreover, research productivity may also refer to the research publications of faculty members in various reputable journals [8]. Measuring research productivity would include several indicators such as researchers' total publications [9] [10]; publications per higher education institution [11]; research areas [10]; authorship [12]; and publications per researcher [6] [7] [8]. This indicates that research productivity can be described in quantifiable terms.

\subsection{The Human Movement Sciences as a Discipline}

The amalgamation of various disciplines that could relate to more than just the term "physical education" resulted in the word "Movement Sciences" which was first coined in 1984 [13]. Ojeme [13] further discerned that considering the term "human movement studies" will gather all the various areas such as health education, sports medicine and administration, physical education, and physical recreation as sub-groups under the discipline of human movement science (HMS). HMS was also described by Starosta [14] as a multidisciplinary field rooted in anthropological, sociological, psychological, and biological perspectives. Additionally, Tinning [15] referred to HMS as a diverse field that pertains to the teachings and studies associated with "movement culture" particularly in physical activities that involve exercise and sport. Also, the emergence of various terms such as "sport, sport science, exercise science, human performance, movement science, human kinetics, kinesiology, kinanthropology, health, physical culture, recreation, leisure studies, and other terms" was manifested in American and European countries through the related discipline of kinesiology [16].

The reason for the emergence of human movement science programs in the Philippines could be associated with the University of the Philippines Diliman and the University of Santo Tomas offering exercise and sports science programs, and the conduct of research studies relevant to the field since these are the pioneer institutions to offer sports science and PE programs in the country [17]. In respect to the research investigations, some faculty members and graduate students attend and present their research outcomes at various local and international conferences, annually [17]. Most of the proposed research papers were from faculty research projects which were being submitted to international journals; hence, the number of international publications grew over the years [17].

\subsection{Bibliometric and Social Network Analysis}

An early definition of bibliometric analysis was given by Pritchard [18] which is the use of mathematical and statistical methods to analyze the different aspects of a written document. Moreover, bibliometric analysis has been extensively utilized to give comprehensive results and provide a structure of knowledge from collected pieces of literature [19]. In this study, the term was used as a method to describe the productivity of research in the field of HMS through the employment of statistical procedures.

Researchers in various fields of specialization who studied social structures in a particular industry utilized social network analysis (SNA) as a method to assess the interrelatedness of their data [10] [20] [21] [22] [23] [24] [25] [26] [27]. For instance, Gilbert et al. [22] applied SNA as their method to analyze the changes in the social network of communities and hierarchical structures. The impact of leadership development and leadership progress was also analyzed with the help of SNA upon evaluating the leadership networks [24]. Moreover, it was revealed that through SNA, those employees with direct connections with their co-workers tend to have a similar perception of organizational support [27]. In terms of research collaborations, several researchers applied SNA in studying the social networks of European [20] and Iranian researchers [26]. Even in the field of disaster preparedness, SNA as a methodology was employed. This was manifested in the study of Kim and Hastak [25] where they analyzed the characteristics of social networks after a disaster hit Louisiana, in the United States. It was discovered that the dissemination of emergency information through social networks helped the researchers to grasp the importance of the usage of social media in propagating the emergency response. Also, Bringula et al. [10] analyzed the research status of Information Technology (IT) Education research in the Philippines using SNA and collected bibliographic data from two (2) conferences in the country, namely the National Conference of IT Education and Philippine 
Computing Society Conference. Private institutions covered the top ranks for the most productive higher education institutions [10]. Overall, these studies indicate that SNA is an emerging and useful methodology in the process of investigating social networks.

While most of the literature indicated the vast use of SNA as an essential means to explore connections between and among researchers in different fields of discipline within and outside the Philippines, there is still limited empirical evidence indicating its utility in unexplored areas such as the emerging field of HMS. Moreover, since the Philippines still views physical education and sports science as the most common fields of interest in the realm of HMS, the changing educational and industrial landscape of the field must adhere to the international premises, specifically in research productivity. The attempt to use SNA to extract knowledge from the research data would respond to the need for further investigations toward describing productivity in HMS.

With the researchers' desire to contribute their share in the ever-dynamic body of knowledge in physical education, this was an initial attempt to examine the researchers and assess the prevalence of research in the field of HMS. It may also serve as a model for future collaborative projects by forming potential networks of institutions with similar research interests. The results of the study may also be used as a reference for a starting scheme to establish HMS-focused journals published in the Philippines.

\subsection{Objective of the Study}

The researchers aimed to describe the status of research productivity in the HMS in the Philippines through the aid of descriptive bibliometric analysis and SNA. Specifically, the study aimed to investigate the status of HMS research publications in terms of:

a) total publications;

b) publications per HEI;

c) publications per researcher;

d) authorship;

e) research areas; and

f) authors' networks.

\section{Materials and Methods}

\subsection{Sources of Data, Data Collection Procedure, and Sample Size}

Google Scholar (GS) was predicted to become a valuable tool for gathering scholarly information [28] [29] [30]. When compared to other major databases (e.g.,
Academic Search Elite, GEOBASE, POPLINE, Scopus, Clarivate Analytics-Web of Science) in terms of coverage, GS yielded the most number of articles indexed [31]. Gehanno et al. [32] for their part, claimed that GS is becoming increasingly known for bibliographic databases which could be used for systematic reviews. For these reasons mentioned, GS was used in this study.

A total of 547 initial research papers were identified and manually extracted from the GS database using the following criteria: the publication date must be within January 2010 to June 2021, and contain the words "Philippines" and of any, but not limited to the following terms: physical education, biomechanics, exercise, exercise science, exercise psychology, health education, health literacy, motor control, movement education, physical activity, physical fitness, sport science, sport psychology, or sports management. The 547 extracted articles which contained their meta-data (i.e., title of the paper, publication date, authors, authors' affiliations) including the keywords were encoded and archived using a spreadsheet software. The researchers sought the aid of three (3) research experts to identify if a research paper falls within the realm of HMS. If the first two experts initially do not agree with one article, the third expert will settle the conflict. After the deliberation, the final dataset contained 274 research publications.

\subsection{Data Cleaning, Pre-processing, and Analysis}

Prior to analysis, the dataset was subjected to data cleaning. The process contained removal of any unreadable and special characters, alphanumeric, periods, commas, colons, semi-colons, hyphens, question marks, quotation marks, slashes, and ampersands from the titles of the papers. Descriptive statistics such as frequency counts and percentages were utilized to determine the publication information, including the top research area according to keywords used. In analyzing the affiliation of each article, HEIs with multiple campuses were counted and tallied together. For authors' names, out of 820 names found within the dataset, only 557 were retained.

For a text and social network analysis, Python programming and Gephi Analysis software were used, respectively. Using Python programming, the text analysis was employed to determine the most frequently used words and trigrams found in research titles. Trigrams are written units with bands of three consecutive words which are typically in the forms of letters, syllables, or words. Meanwhile, Gephi Analysis software was utilized to determine the possible clusters that can be found within the dataset. In addition, modularity, which measures the strength of network division but with sparse connection with other networks, was used to identify the densest authors' network [33]. 


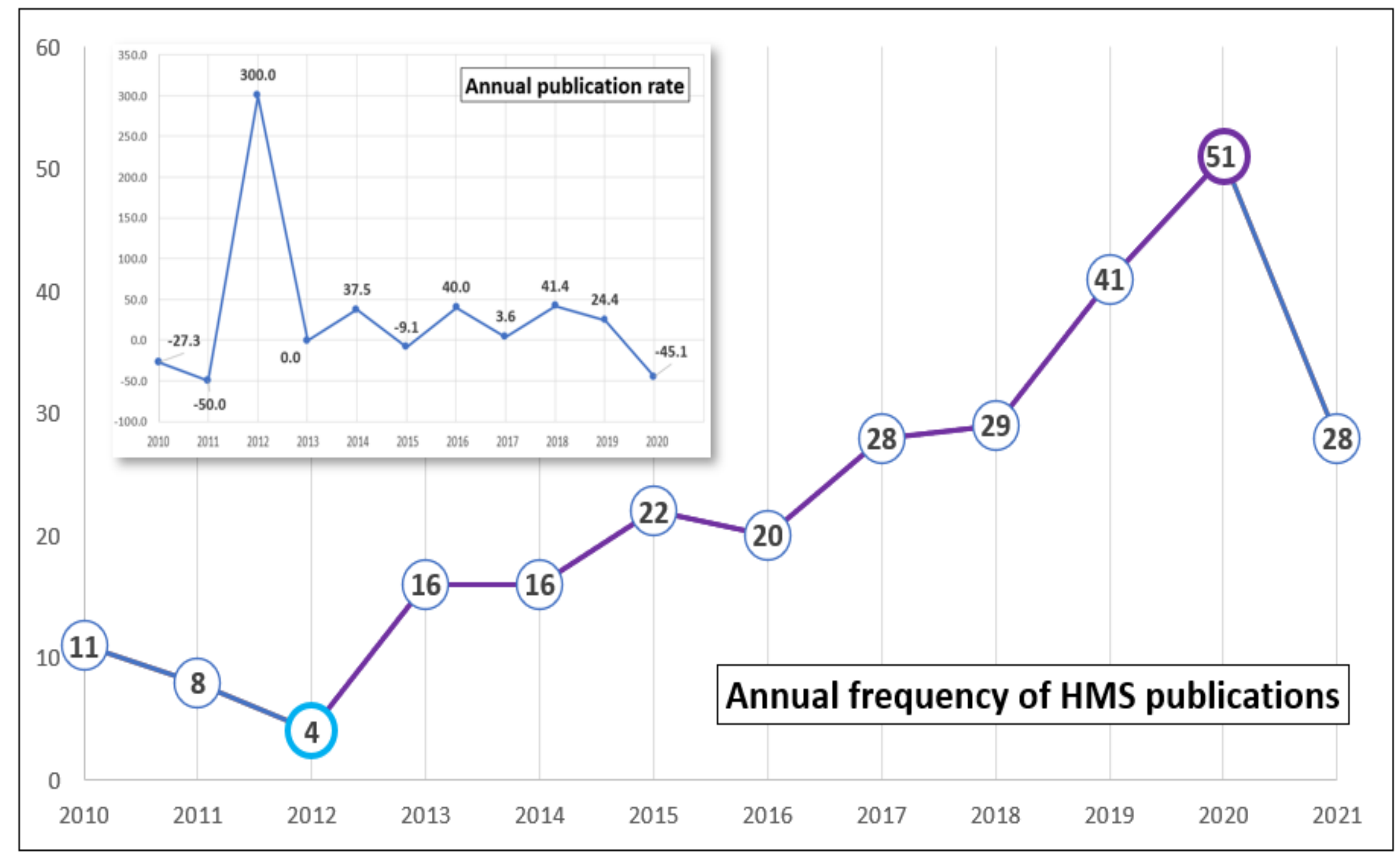

Figure 1. HMS research rate of publication per year 


\section{Results and Discussion}

\subsection{Total Publications}

Figure 1 indicates that HMS-related publications indexed in GS are steadily rising from 2012 onwards. The average publication rate was $28.6 \%$ from January 2010 to June 2021. Even though there is an increase in the research publications in terms of frequency, it can be observed that the publication rate is unstable but indicates distinct progress. These results, when compared to Nguyen and Pham's [34] report show that the Philippines' contribution to ASEAN research outputs from 1991 to 2010 is merely five (5) percent. Vinluan [35] shared the same findings when she reported that the Philippines is lagging behind their ASEAN peers when it comes to research publication. However, a more recent study showed a promising result indicating that the country landed fifth in terms of research publication output [36]. The country outperformed its ASEAN-neighboring countries when it comes to educational research publications that are indexed in the Scopus database [36].

As shown in Figure 2, most of the publications for HMS-related articles found within the dataset are mostly in international peer-reviewed journals $(n=245)$. It could be inferred that the research publications of Filipino authors in the field of HMS have mostly penetrated the international mainstream. This enables the possibility that their work could be read by a global network of fellow researchers in the field which could be a strong platform for possible citations and utilization of results or findings. Based on the analysis, there is no specific journal found that is intended or solely focused on HMS in the Philippines. As Figure 2 indicates, seven (7) percent of the publications originated locally. This was supported by the study of Tecson-Mendoza [37] who reported that most of the journals in the country are intended for medical-related research and only 28 out of 777 Philippine scientific and academic journals are registered in major indexing databases.

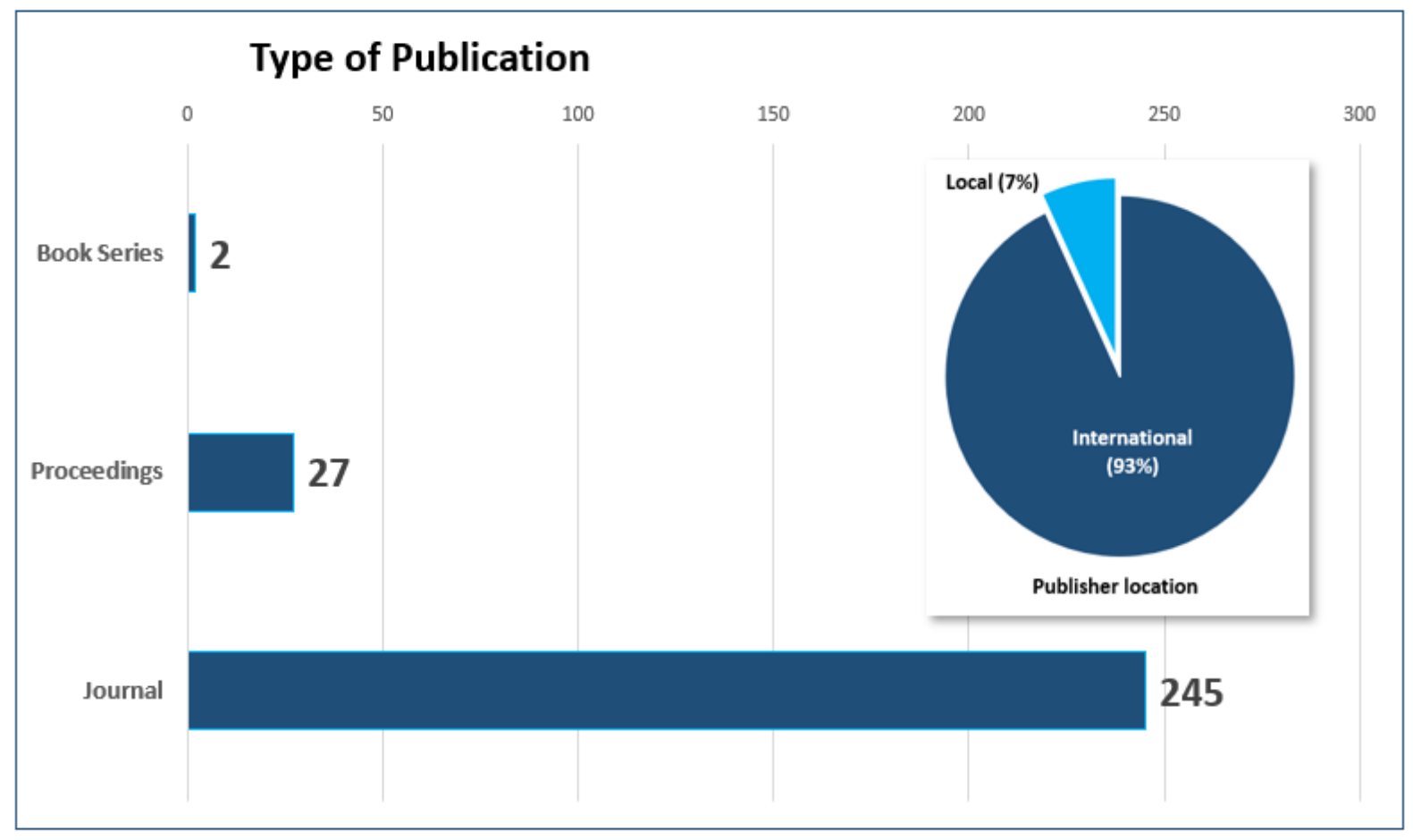

Figure 2. HMS research publications based on the type of paper and location of publisher 


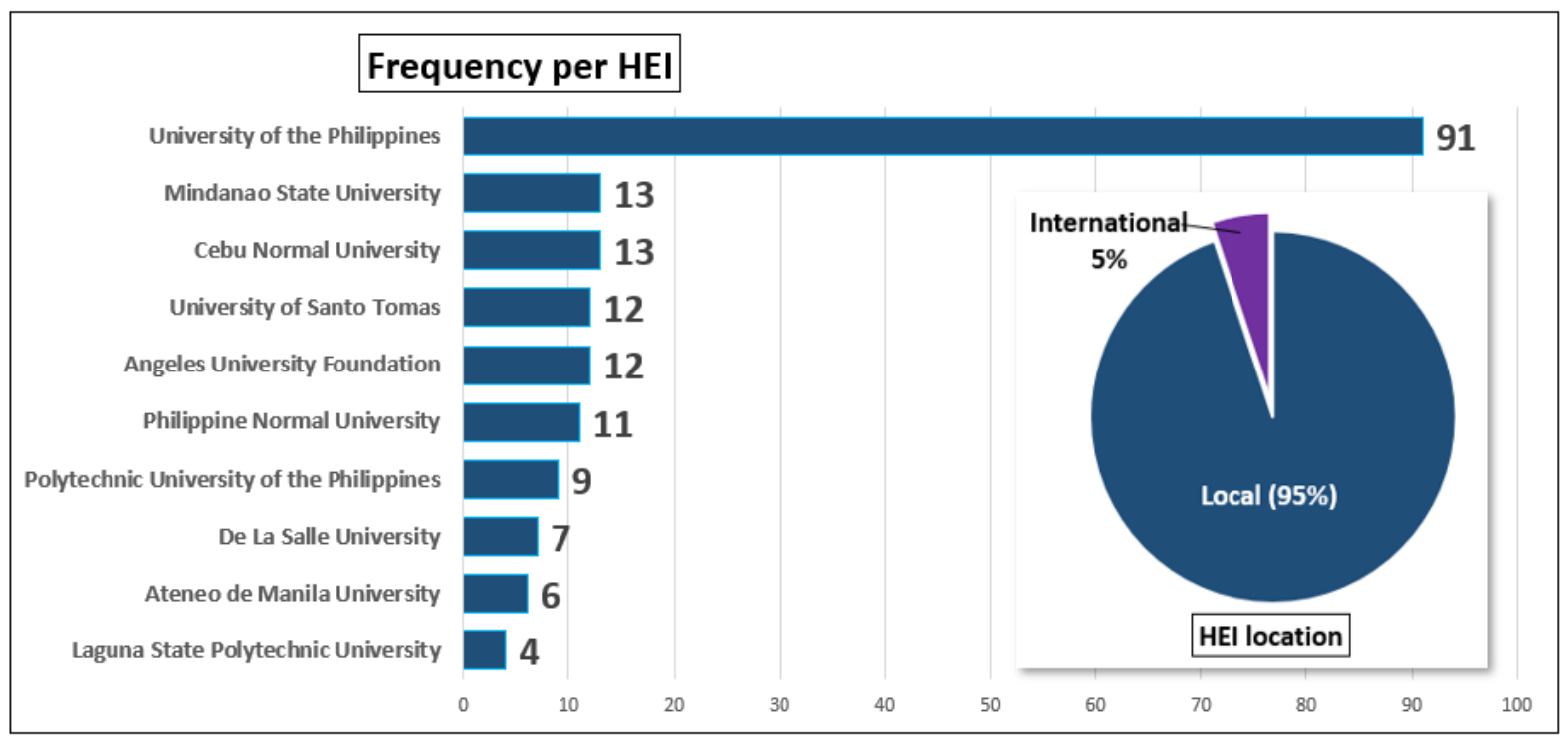

Figure 3. Top 10 HEIs and their location based on the first authors' affiliation

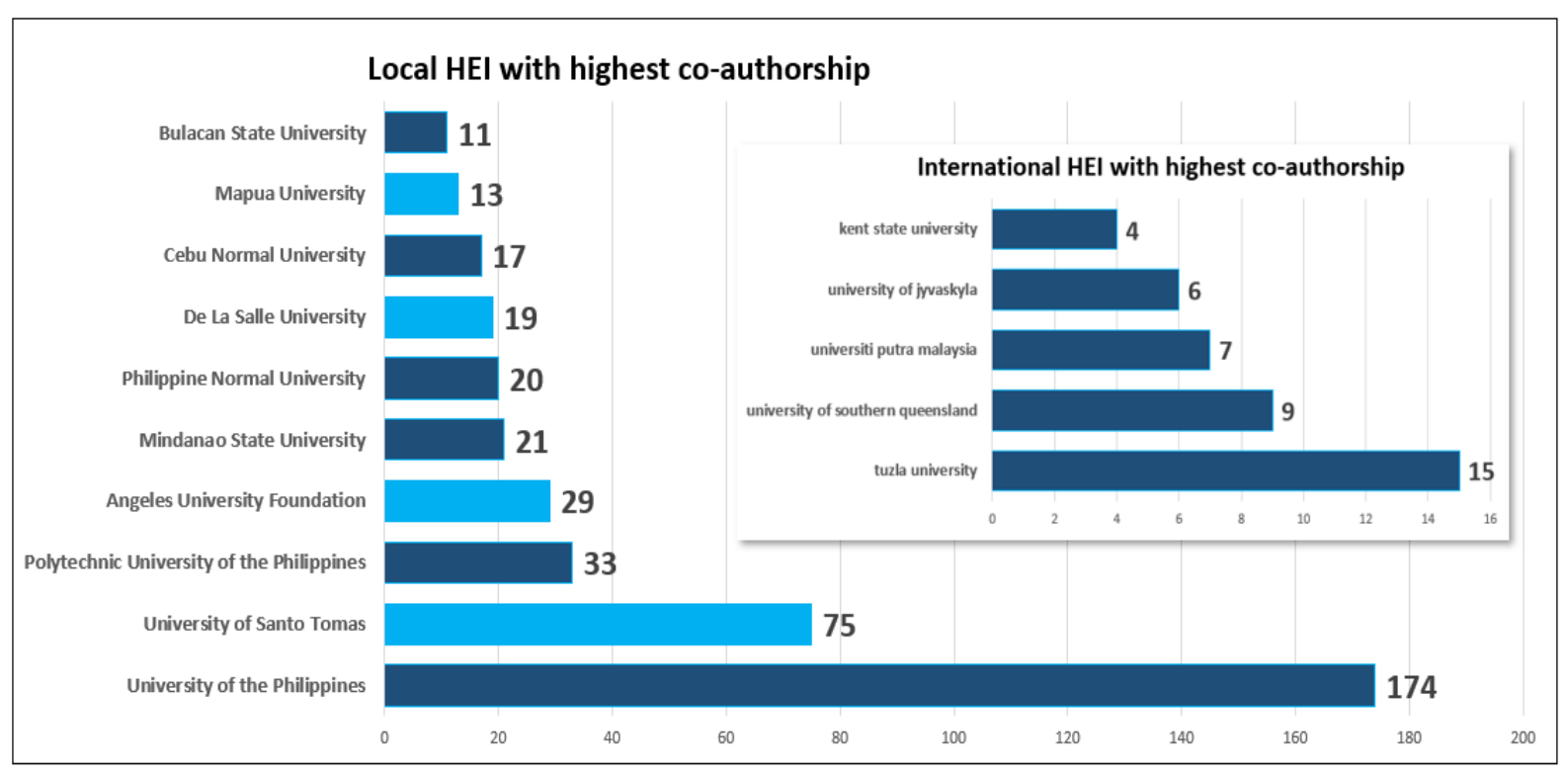

Figure 4. Top HEIs based on co-authorship

\subsection{Publications per HEI}

There were 78 identified affiliations within the dataset, but only 74 remained, as the other four (4) were not considered as HEIs (i.e., basic education, government institutions). Most of the affiliations in the articles were local. This is true as the identification and screening process initially used the word "Philippines" as a criterion. Also, five (5) percent of the HEIs in the study have been affiliated internationally $(n=13)$.

As shown in Figure 3, the University of the Philippines (UP) is the most prolific HEI in terms of research production found in the dataset $(n=91)$. This was determined by their first author affiliation. On average, the top ten (10) HEIs published approximately 18 research articles from January 2010 to June 2021. Furthermore, six (6) out of the ten (10) HEIs are publicly funded institutions.

In terms of co-authorships, UP was also identified as the HEI with the most co-authorships which was found within the 174 research papers in the dataset (Figure 4). While internationally, Tuzla University has the highest frequency of co-authorship with other Philippine HEIs ( $n$ $=15$ ). The same observation was found indicating that the HEIs with most co-authorships are publicly funded. This indicates that the Philippines' premier state university (UP) continuously produces several research outputs.

The results were further justified by Madrigal et al. [17] upon looking at how instruction and research in the field of exercise and sports sciences were examined at the 
University of the Philippines and the University of Santo Tomas on a comparative scheme. While UP, particularly in its Diliman campus, maintains its College of Human Kinetics, the University of Santo Tomas institutionalized a Department of Sports Science under the College of Rehabilitation Sciences, which sustains a Center for Health Research and Movement Science. The two universities are the pioneering institutions to offer exercise and sports science programs and the conduct of research articles relevant to the field in the Philippines. Most of the proposed papers which were being submitted to international journals were mainly from the faculty members and eventually contributed to the growing number of research publications [17].

\subsection{Publications per Researcher}

Table 1 shows that the most prolific researcher within the dataset was Jeffrey Pagaduan from UP $(n=18)$. Pagaduan was also the lone researcher to be affiliated with foreign HEIs when the list is further stretched to the 10 most published names. Furthermore, UP dominated the list when it comes to the main authorship as seen in Table 2. On average, the top three authors (Pagaduan, Cagas, \& Buot) published at least one research article per year.
Additionally, there is an upward trend when it comes to their publication rate.

For the main authorship (also referred to as a lead or the first author), Merites Buot from UP topped the list. Only UP $(n=28)$ and Cebu Normal University (CNU) $(n=6)$ lead the affiliation of the main author of the research publications found in the dataset. The observed productivity in the University of the Philippines System may be attributed to its intensive efforts to capacitate its faculty members and researchers through funding [38]. Moreover, internationalization in research may have an impact on publishing articles since the top author with the highest number of publications has been affiliated with an international university. These results corroborate with the study of Kwiek [39] which revealed that the connection to international cooperation and collaborations could contribute to productivity in research. Moreover, this could be associated with the presence of the College of Human Kinetics in UP that also helped in producing such outputs. Similar to this, the study of Gümüs et al. [40] analyzed the research publications in the ERIC database where the top two productive researchers came from the institutions with a department intended for human movement sciences.

Table 1. Top 5 researchers based on the number of publications from January 2010 to June 2021

\begin{tabular}{|c|c|c|c|c|}
\hline \multirow{2}{*}{ Rank } & Author & Affiliation & Frequency & Total Publication \\
\hline \multirow{2}{*}{1} & Jeffrey Pagaduan & University of the Philippines & 2 \\
\cline { 2 - 5 } & Jonathan Cagas & University of Tasmania & 16 \\
\hline 2 & Merites Buot & University of the Philippines & 11 & 13 \\
\hline 3 & Christian Wisdom Valleser & University of the Philippines & 8 & 8 \\
\hline 4.5 & Consuelo Gonzalez-Suarez & University of Santo Tomas & 8 & 8 \\
\hline
\end{tabular}

Table 2. Top 5 authors based on main authorship

\begin{tabular}{|c|c|c|c|}
\hline Rank & Author & Frequency & Affiliation \\
\hline 1 & Consuelo Gonzalez-Suarez & 9 & University of Santo Tomas \\
\hline 2.5 & Jeffrey Pagaduan & 7 & University of the Philippines \\
\hline 2.5 & Christian Wisdom Valleser & 5 & University of the Philippines \\
\hline 4.5 & Jonathan Cagas & 1 & University of the Philippines \\
\hline 4.5 & Marino Garcia & 6 & Cebu Normal University \\
\hline
\end{tabular}




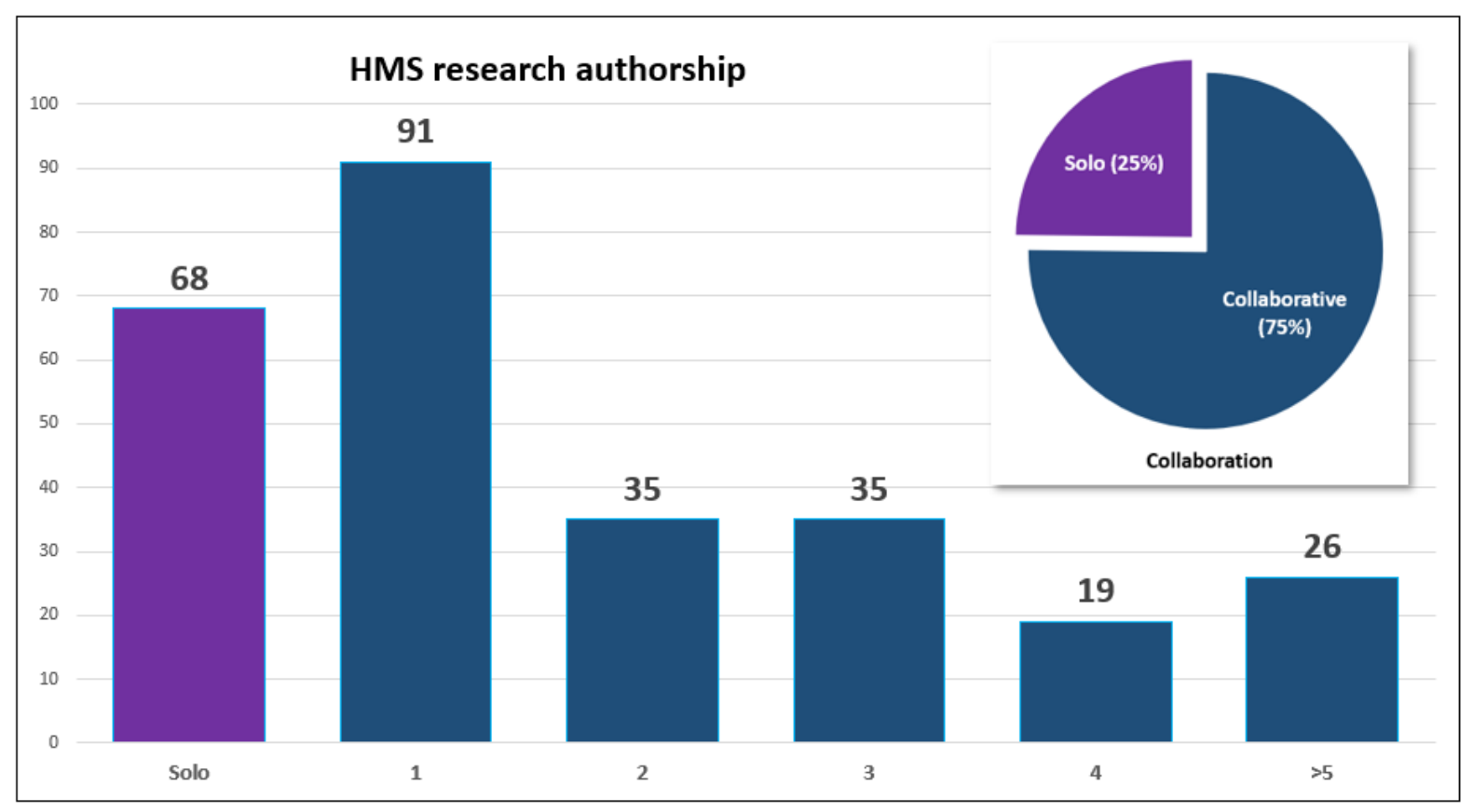

Figure 5. Authors per publication

\subsection{Authorships}

Approximately, a quarter of the articles within the dataset were published by a single author $(n=68)$. Collaboration was evident as seen in Figure 5. Based on the analysis, it specifically shows that collaboration with another author was preferred when it comes to research publications $(n=91)$. Kumar and Ratnavelu [41] mentioned that scholars perceived co-authorship with colleagues with the same socio-academic background as a rewarding experience. According to them, collaborating with peers provides greater benefits such as improved research output and the division of workload. The same view was pointed out by Ward et al. [42] who claimed that the factors for scholarly collaboration are driven by shared cultural orientation, including personal and professional development, and challenges. Moreover, in relation to the collaborative writing in research, Yemini [43], upon interviewing scholars in the field of education from Australia, Denmark, and Israel, posited that such international collaborations are effective in contributing to their research outputs. Also, Kumar and Jan [44] analyzed the research partnerships of Malaysia from the point of view of business and management. They asserted that the country included research and development as a significant agendum in their 2020 Vision program. In the same study, it was reported that most of the researchers in business and management collaborated more with foreign authors rather than the local institutions within the country. It was unexpected that the United States, Australia, Japan, United Kingdom, and Canada were the top collaborators of the country since Malaysia is one of the distinguished countries in the Association of Southeast Asian Nations (ASEAN).

\subsection{Research Areas}

Table 3. Top 5 HMS research areas according to the keywords used

\begin{tabular}{|c|c|c|c|}
\hline Rank & Keyword & Frequency & Top Contributor \\
\hline 1 & $\begin{array}{c}\text { physical } \\
\text { education }\end{array}$ & 24 & Jeffrey Pagaduan (UP) \\
\hline 2 & $\begin{array}{c}\text { physical } \\
\text { activity }\end{array}$ & 16 & Anatalia Endozo (AUF) \\
\hline 3 & $\begin{array}{c}\text { physical } \\
\text { fitness }\end{array}$ & 10 & $\begin{array}{c}\text { Consuelo } \\
\text { Gonzalez-Suarez (UST) }\end{array}$ \\
\hline 4.5 & motivation & 8 & Jonathan Cagas (UP) \\
\hline 4.5 & $\begin{array}{c}\text { academic } \\
\text { performance }\end{array}$ & 8 & $\begin{array}{c}\text { Christian Wisdom } \\
\text { Valleser (UP) }\end{array}$ \\
\hline
\end{tabular}

There were 931 unique keywords used by researchers found in the dataset. Table 3 shows that the most frequently used keyword for research publications was "physical education" $(n=24)$. Jeffrey Pagaduan from UP contributed the most in this area. Additionally, findings show that physical education was the focus area in HMS among researchers from January 2010 to June 2021. Table 3 further indicates that papers are mostly tagged under movement pedagogy (e.g., physical education, activity, and fitness, etc.). Similar findings were reported from the study of Khoo et al. [45] and González et al. [46]. In addition, Tomanek and Lis [47] also reported the occurrence of "physical education" and "student" as the most common words being used in the field of physical education research. Also, Gümüs et al. [39] reported in their bibliometric analysis in physical education and sports that the prominent words cited in most publications from the Education Resources Information Center (ERIC) databases are "physical education" and "physical activity." This implies that the extensive use of these keywords in HMS-related disciplines defines the strong research 
interest of many researchers in physical education and physical activity.

Table 4. Most common words found within HMS research titles

\begin{tabular}{|c|c|c|c|}
\hline Rank & Word & Frequency & Sample Title \\
\hline 1 & physical & 81 & $\begin{array}{c}\text { The basic psychological } \\
\text { needs in Physical Education } \\
\text { Scale in Filipino: An } \\
\text { exploratory factor analysis } \\
\text { [48] }\end{array}$ \\
\hline 2 & student & 55 & $\begin{array}{c}\text { Impact of physical education } \\
\text { related activities in the } \\
\text { holistic development of } \\
\text { students in state universities } \\
\text { and colleges in Northern } \\
\text { Philippines [49] }\end{array}$ \\
\hline 3 & activity & 43 & $\begin{array}{c}\text { Potential factors in engaging } \\
\text { physical activity beyond } \\
\text { Physical Education class [50] }\end{array}$ \\
\hline 4 & education & 41 & $\begin{array}{c}\text { Development and evaluation } \\
\text { of localized digital learning } \\
\text { modules for indigenous } \\
\text { peoples' health education in } \\
\text { the Philippines [51] }\end{array}$ \\
\hline 5 & athlete & 38 & $\begin{array}{c}\text { Sports teachers coaching style } \\
\text { behavior competency and } \\
\text { student athletes performance } \\
\text { in sports [52] }\end{array}$ \\
\hline
\end{tabular}

Table 5. Most common trigrams found within HMS research titles

\begin{tabular}{|c|c|c|c|}
\hline Rank & Word & Frequency & Sample Title \\
\hline 1 & $\begin{array}{c}\text { physical } \\
\text { activity } \\
\text { participation }\end{array}$ & 6 & $\begin{array}{c}\text { Current exercise habits and } \\
\text { factors affecting physical } \\
\text { activity participation } \\
\text { among university students } \\
\text { [53] }\end{array}$ \\
\hline 2 & $\begin{array}{c}\text { physical } \\
\text { pducation } \\
\text { program }\end{array}$ & 5 & $\begin{array}{c}\text { Quality assessment of } \\
\text { Physical Education } \\
\text { program of state } \\
\text { universities in the } \\
\text { Philippines [54] }\end{array}$ \\
\hline 4 & $\begin{array}{c}\text { high school } \\
\text { student }\end{array}$ & 4 & $\begin{array}{c}\text { Acute effect of } \\
\text { birdwatching on mood } \\
\text { states of senior high } \\
\text { school students in the } \\
\text { Physical Education setting } \\
\text { [55] }\end{array}$ \\
\hline 4 & $\begin{array}{c}\text { Aniversities } \\
\text { colleges }\end{array}$ & 4 & $\begin{array}{c}\text { Adapted Physical } \\
\text { Education program for } \\
\text { handicapped students } \\
\text { among state universities } \\
\text { and colleges in Region I } \\
\text { of the Philippines [56] }\end{array}$ \\
\hline 4 & $\begin{array}{c}\text { Physical activity and } \\
\text { physical fitness among } \\
\text { physical } \\
\text { activity } \\
\text { physical }\end{array}$ & 4 & $\begin{array}{c}\text { Filipino university students } \\
\text { [57] }\end{array}$ \\
\hline
\end{tabular}

In terms of frequently used words in publication titles, "physical" $(n=81)$ topped the list (Table 4). This was also supported in Table 5. By using text analysis to produce the common trigrams found within research titles, the results show that most papers within the dataset are mostly focused in the context of both students and the academia (e.g., physical activity participation, physical education program, high school student) and was the most studied topic found in the dataset based on the title of the papers. Considering the number of authors who belong to the academe, this justifies the results as they are required to produce such outputs [2] [4] [5] [6].

\subsection{Social Network Clusters}

Using the SNA, seven (7) main networks were found (Figure 6). The distinguished researcher identified with the largest network (i.e., Cluster 1 with 35 co-authors) was Consuelo Gonzalez-Suarez (University of Santo Tomas). Consuelo Gonzalez-Suarez was able to collaborate with most of them from UST $(n=32)$. Moreover, she co-authored with three other non-UST-affiliated researchers such as Francisco Delos Reyes from UP, Masayoshi Kubo from the Niigata University of Health and Welfare, and Karen Grimmer-Somers from the University of South Australia. The next clusters found were as follows: Marla Frances Mallari (UP), (Cluster 2 with 12 co-authors); Jeffrey Pagaduan (UP), (Cluster 3 with 32 co-authors); Jonathan Cagas (UP), (Cluster 4 with 19 co-authors); Ertie Abana (Benguet State University) and Nicole Angelo Malpaya (University of Saint Louis), (Cluster 5 with 11 co-authors); Jonar Martin (Angeles University Foundation), (Cluster 6 with 18 co-authors); and Lualhati Dela Cruz (Polytechnic University of the Philippines), (Cluster 7 with 4 co-authors). These authors' network was identified from the dataset using modularity as a criterion which measures the connection density and the strength of network structure. The SNA identified the most prolific scholars in the field of HMS that are found in GS from January 2010 to June 2021. Furthermore, the results indicate that most researchers in HMS mostly collaborate with their peers within their universities, particularly those HEIs with proximity to one another. This means that research collaboration often takes place within institutions and common groups [58] [59]. This also signifies that research collaborations contribute well to the level of productivity of the researchers. Relative to this, Abbasi et al. [58] mentioned that researchers who collaborate with their networks perform better, most specifically if the collaboration is within the institution. Moreover, Aldieri et al. [60] also pointed out the importance of research collaborations in academic performance. The improvement of quality in research was grounded on the flow of knowledge among the researchers and their established networks. Li et al. [61] stated that working with prolific researchers may increase chances of productivity, though they centered particularly on the increase in the number of citations. The present study revealed that the establishment and determination of networks of researchers in the field of human movement sciences facilitates the identification of prolific scholars who continuously aid in the development of the ever-changing educational and scientific landscape of the discipline. 


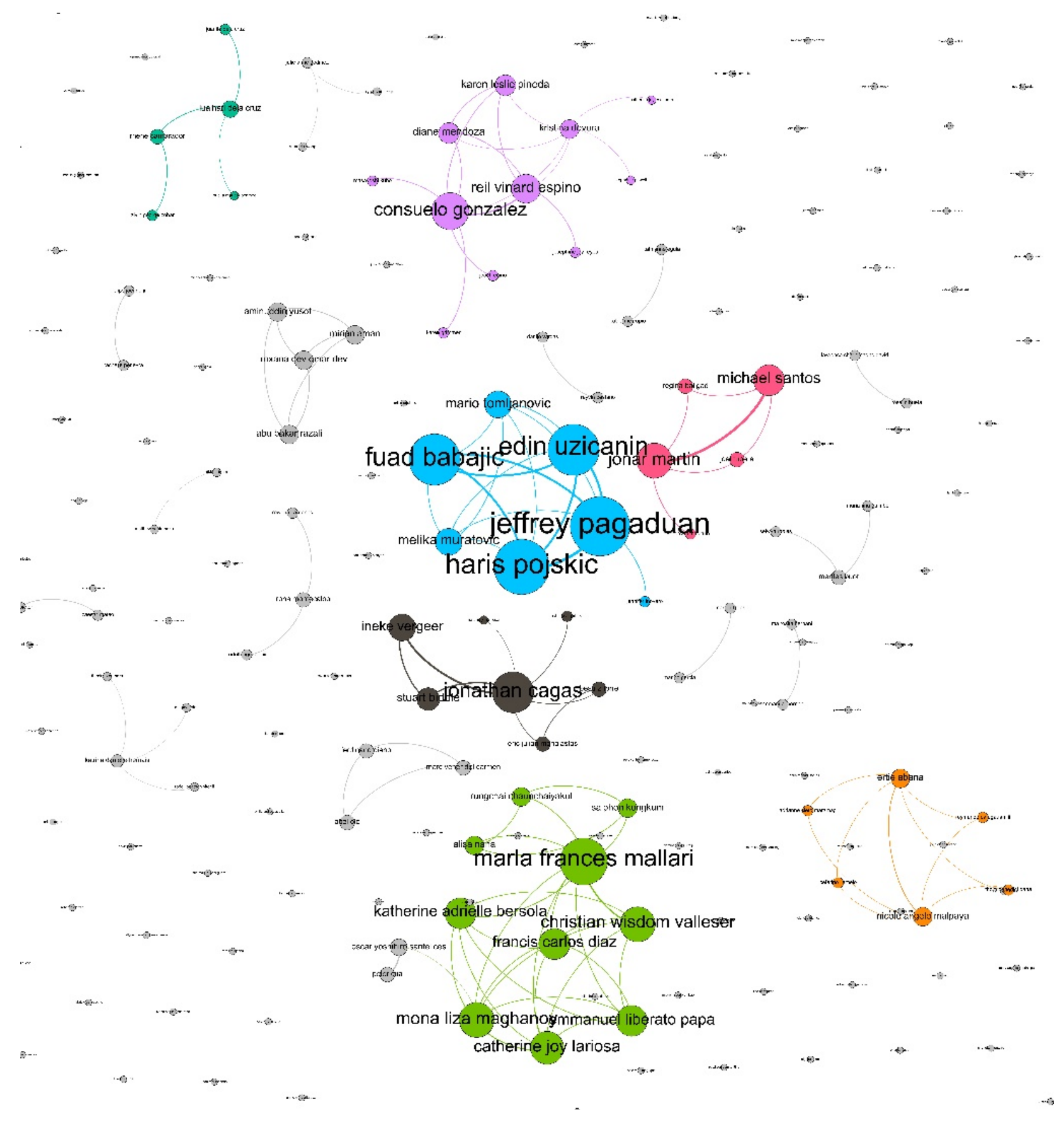

Figure 6. Authors' social network

\section{Conclusion and Limitation of the Study}

The outcomes of the study identified notable patterns, top universities, top researchers, co-authorship strategies, and specific areas of HMS in describing the status of research productivity through a bibliometric analysis. Also, based on the articles extracted and indexed from GS from January 2010 to June 2021, an unstable publication rate was observed.

Public HEIs occupied the top ranks based on the number of HMS research publications. UP is the top university that excelled in the total number of research publications, making it the most productive HEI in producing HMS-related publications. In addition, the study identified the most prolific HMS researchers, and research collaboration is common, where oftentimes, researchers collaborate with their institutional peers. The study also identified that physical education was still the top research area for HMS, making PE the most explored discipline. The study also showed that the topic was heavily studied in the academic context. For the authors' networks, the study provided a glimpse of the clusters that can be found within the realm of HMS, particularly those indexed in GS. 
The study is limited to understanding the research productivity in the Philippines based on the meta-data of HMS-related publications indexed in the GS database. The study briefly described the dataset extracted from the database and performed descriptive bibliometric analysis, text analysis, and SNA.

\section{Future Works}

While the study provided insights and status about HMS publications from June 2010 to July 2021 that are indexed in GS, the authors acknowledge that more research needs to be done. Future works may include the conduct of the same research with the inclusion of other major indexing databases such as Scopus, IEEE Xplore, ACM Digital Library, ASEAN Citation Index, and Web of Science. Impact and further analysis of abstract and citations between and among publications of authors, with and from the Philippines, are also worth pursuing. Analysis and comparison using new, or the same dataset can also be initiated.

\section{Implications}

As an initial attempt to investigate the network of researchers and assess the prevalence of research papers in HMS, the study will serve as a benchmark of present and future research undertakings in this dynamic field. In addition, this may pave the way toward the promotion of HMS research to be eventually considered as one of the emerging research agenda in Philippine higher education. This will also lay the foundation of potential networks of institutions sharing the same research niche for future collaborative undertakings to improve the field in mainstream academia. As the study also identified the research authorities in HMS, it will potentially rationalize the emergence of research undertakings that focus on thematic areas of HMS, since research dissemination and utilization are considered as binding elements of a productive organization in a particular discipline. Moreover, this could be a starting scheme to establish HMS-focused journals that are locally published in the Philippines.

\section{Conflict of Interest}

The authors declare no conflict of interest and the funders had no role in the design of the study; in the collection, analyses, or interpretation of data; in the writing of the manuscript, or in the decision to publish the results.

\section{REFERENCES}

[1] K. Akarowhe. Translational research: Definitions and relevance, Journal of Biology and Medical Research, Vol. 2, No.2, 1-4, 2018. https://www.imedpub.com/articles/transla tional-research-definitions-andrelevance.pdf.

[2] E. Z. Cameron, M. E. Gray, A. M. White. Is publication rate an equal opportunity metric?, Trends in Ecology \& Evolution, Vol. 28, No. 1, 7-8, 2012.https://doi.org/10.101 $6 /$ j.tree.2012.10.014.

[3] K. L. Webber. Measuring faculty productivity. In: Shin J., Toutkoushian R., Teichler U. (eds) University Rankings, The Changing Academy - The Changing Academic Profession in International Comparative Perspective, Springer, Dordrecht, Vol. 3, 105-121, 2011. http://doi.org/10.1007/978-94-007-1116-7_6.

[4] S. Lahiri, V. Kumar. Ranking international business institutions and faculty members using research publication as the measure, Management International Review, Vol. 52, 317-340, 2012.https://doi.org/10.1007/s11575-011-0116-x

[5] I. Lee. Publish or perish: The myth and reality of academic publishing, Language Teaching, Vol. 47, No. 2, 250-261, 2014. https://doi.org/10.1017/S0261444811000504.

[6] G. Abramo, C.A. D'Angelo. How do you define and measure research productivity?, Scientometrics, Vol. 101, 1129-1144, 2014. https://doi.org/10.1007/s11192-014-126 9-8.

[7] L. P. Nygaard. Publishing and perishing: An academic literacies framework for investigating research productivity, Studies in Higher Education, Vol. 42, No. 3, 519-532, 2015. https://doi.org/10.1080/03075079.2015.1058351.

[8] M. C. Tremblay, D. VanderMeer, R. Beck. The effects of the quantification of faculty productivity: Perspectives from the design science research community, Communications of the Association for Information Systems, Vol. 43, 625-661, 2018. https://doi.org/10.17705/1CAIS.04334.

[9] A. Brew, D. Boud. Understanding academics' engagement with research, In A. Brew \& L. Lucas (Eds.), Academic Research and Researchers. SRHE and the Open University Press, 2009. https://eprints.mdx.ac.uk/id/eprint/21448.

[10] R. Bringula, M. Racelis, R. C. Rodrigueza. Who's who in the Information Technology research in the Philippines, In Proceedings of Philippine Computing Science Congress (PCSC2019), 2020. https://doi.org/10.1145/1234567890.

[11] R. K. Toutkoushian, S. R. Porter, C. Danielson, P. R. Hollis. Using publications counts to measure an institution's research productivity, Research in Higher Education, Vol. 44, 121-148, 2003. https://doi.org/10.1023/A:1022070227 966

[12] A. Kuzhabekova. Impact of co-authorship strategies on research productivity: A social-network analysis of publications in Russian cardiology, University of Minnesota, 2011. https://conservancy.umn.edu/bitstream/h andle/11299/108109/Kuzhabekova_umn_0130E_11805.pd $\mathrm{f}$ ? sequence $=1$ \&isAllowed $=\mathrm{y}$.

[13] E. O. Ojeme. Has the name, physical education, outlived its usefulness?, Physical Educator, Vol. 41, No. 4, 190, 1984 https://www.proquest.com/openview/182d8be9724f525d1 cb1390fa070645e/1?pq-origsite $=$ gscholar $\& \mathrm{cbl}=2030480$. 
[14] W. Starosta. Science of human movements - meaning, name directions of development, Journal of Human Kinetics, Vol. 6, 3-22, 2001.http://www.johk.pl/files/01_st a.pdf.

[15] R. Tinning. Pedagogy and human movement theory, practice, research. Routledge, 2010. https://doi.org/10.432 4/9780203885499.

[16] Z. Čustonja, D. Milanović, G. Sporiš. Kinesiology in the names of higher education institutions in Europe and the United States of America, Kinesiology, Vol. 41, No. 2, 136-146, 2009. https://hrcak.srce.hr/index.php?show=clan ak\&id_clanak_jezik=70891.

[17] N. Madrigal, J. J. Reyes, J. Pagaduan, R. V. Espino. Exercise science academic programs and research in the Philippines, International Journal of Exercise Science, Vol. 3, No. 4, 157-164, 2010.https://www.ncbi.nlm.nih.gov/pm c/articles/PMC4738868/.

[18] A. Pritchard. Statistical bibliography or bibliometrics?, Journal of Documentation, Vol. 25, No. 4, 348-349, 1969. https://ci.nii.ac.jp/naid/10019400686/.

[19] R. Rialti, G. Marzi, C. Ciappei, D. Busso. Big data and dynamic capabilities: A bibliometric analysis and systematic literature review, Management Decision, Vol. 57, No. 8, 2052-2068, 2019. https://doi.org/10.1108/MD-0 7-2018-0821.

[20] R. S. Behara, S. Babbar, P. A. Smart. Leadership in OM research: A social network analysis of European researchers, International Journal of Operations \& Production Management, Vol. 34, No. 12, 1537-1563, 2014. https://doi.org/10.1108/IJOPM-08-2013-0390.

[21] B. Ghafouri, H. Mohammadhassanzadeh, F. Shokraneh, M. Vakilian, S. Farahmand. Social network analysis of Iranian researchers on emergency medicine: A sociogram analysis, Emergency Medicine Journal, Vol. 31, No. 8, 619-624, 2014. http://dx.doi.org/10.1136/emermed-2012-201781.

[22] F. Gilbert, P. Simonetto, F. Zaidi, F. Jourdan, R. Bourqui. Communities and hierarchical structures in dynamic social networks: Analysis and visualization, Social Network Analysis and Mining, Vol. 1, 83-95, 2011. https://doi.org/10.1007/s13278-010-0002-8.

[23] M. E. Hambrick. Six degrees of information: Using social network analysis to explore the spread of information within sport social networks, International Journal of Sport Communication, Vol. 5, No. 1, 16-34, 2012. https://doi.org/10.1123/ijsc.5.1.16.

[24] B. Hoppe, C. Reinelt. Social network analysis and the evaluation of leadership networks, The Leadership Quarterly, Vol. 21, No. 4, 600-619, 2010. https://doi.org/10.1016/j.leaqua.2010.06.004.

[25] J. Kim, M. Hastak. Social network analysis: Characteristics of online social networks after a disaster, International Journal of Information Management, Vol. 38, No. 1, 86-96, 2018. https://doi.org/10.1016/j.ijinfomgt.2017.08.003.

[26] F. Sadoughi, A. Valinejadi, M. S. Shirazi, R. Khademi. Social network analysis of Iranian researchers on medical parasitology: A year co-authorship survey, Iranian Journal of Parasitology, Vol. 11, No. 2, 204-212, 2016. https://www.ncbi.nlm.nih.gov/pmc/articles/PMC5236097/.
[27] T. J. Zagenczyk, K. D. Scott, R. Gibney, A. J. Murrell, J. B. Thatcher. Social influence and perceived organizational support: A social networks analysis, Organizational Behavior and Human Decision Processes, Vol. 111, No. 2, 127-138, 2010. https://doi.org/10.1016/j.obhdp.2009.11.00 4.

[28] P. Jacsó. Google Scholar: The pros and the cons, Online Information Review, Vol. 29, No. 2, 208-214, 2005. https://doi.org/10.1108/14684520510598066.

[29] A. Noruzi. Google Scholar: The new generation of citation indexes, Libri, Vol. 55, No. 4, 170-180, 2005. https://doi.org/10.1515/LIBR.2005.170.

[30] J. Gray, M. Hamilton, A. Hauser, M. Janz, J. Peters, F. Taggart. Scholarish: Google Scholar and its value to the Sciences, Issues in Science and Technology Librarianship, Vol. 70, 2012. https://doi.org/10.5062/F4MK69T9.

[31] W. Walters. Google Scholar coverage of a multidisciplinary field, Information Processing and Management, Vol. 43, No. 4, 1121-1132, 2007. https://doi.org/10.1016/j.ipm.2006.08. 006 .

[32] J. Gehanno, L. Rollin, S. Darmoni. Is the coverage of Google Scholar enough to be used alone for systematic reviews, BMC Medical Informatics and Decision Making, Vol. 13, No. 7, 2013. https://doi.org/10.1186/1472-6947-1 3-7.

[33] M. E. J. Newman. Modularity and community structure in networks, Proceedings of the National Academy of Sciences of the United States of America, Vol. 103, No. 23, 8577-8582, 2006. https://doi.org/10.1073/pnas.060160210 3.

[34] T. V. Nguyen, L. T. Pham. Scientific output and its relationship to knowledge economy: An analysis of ASEAN countries, Scientometrics, Vol. 89, 107-117, 2011. https://doi.org/10.1007/s11192-011-0446-2.

[35] L. R. Vinluan. Research productivity in education and psychology in the Philippines and comparison with ASEAN countries, Scientometrics, Vol. 91, 277-294, 2011. https://doi.org/10.1007/s11192-011-0496-5.

[36] R. M. D. Guido, A. V. Orleans. Philippine research productivity in education research: A comparative performance in Southeast Asia, Asia Pacific Journal of Multidisciplinary Research, Vol. 8, No. 4, 76-90, 2020. http://www.apjmr.com/wp-content/uploads/2020/10/APJM R-2020.08.04.09.pdf.

[37] M. Tecson-Mendoza. Scientific and academic journals in the Philippines: Status and challenges, Science Editing, Vol. 2, No. 2, 73-78, 2015. https://doi.org/10.6087/kcse.47.

[38] M. Kwiek. Internationalization and research productivity: "Internationalists" and "locals" in Polish universities., Higher Education in Russia and Beyond, 2014. https://hdl.handle.net/10593/11725.

[39] University of the Philippines Diliman. (2005). Faculty Manual Update. https://www.yumpu.com/en/document/rea d/29631187/faculty-manual-update-2005-ovcaa.

[40] H. Gümüs, C. Gençoglu, T. Sahin. Physical Education and Sports: Bibliometric Analysis of the ERIC Database, International Online Journal of Education and Teaching, Vol. 7, No. 4, 1823-1837. https://files.eric.ed.gov/fulltext/E J1271118.pdf. 
[41] S. Kumar, K. Ratnavelu. Perceptions of scholars in the field of economics on co-authorship associations: Evidence from an international survey, PLoS ONE, Vol. 11, No. 6, e0157633, 2016.https://doi.org/10.1371/journal.pone.0157 633.

[42] P. Ward, E. Devrilmez, S. Ayvazo, F. Dervent, Y. He, P. Iserbyt, L. Ince, I. Kim, B. Ko, W. Li, E. Tsuda. A transnational research collaboration: A social network Analysis and Perspectives on Our Community of Practice, Quest, 2021. https://doi.org/10.1080/00336297.2021.1965 892.

[43] M. Yemini. International research collaborations as perceived by top-performing scholars, Journal of Studies in International Education, 1028315319887392.https://oi/ab s/10.1177/1028315319887392.

[44] S. Kumar, J. M. Jan. Mapping research collaborations in the business and management field in Malaysia, 1980-2010, Scientometrics, Vol. 97, No. 3, 491-517, 2013. https://doi.org/10.1007/s11192-013-0994-8.

[45] S. Khoo, P. Ansari, T. Morris. Sport and exercise psychology research from the Asian and South Pacific region: A bibliometric analysis, Asian Journal of Sport and Exercise Psychology, Vol. 1, No. 1, 21-29, 2021. https://doi.org/10.1016/j.ajsep.2021.03.003.

[46] M. González, X. García-Massó, A. Pardo-Ibañez, F. Peset, J. Devís-Devís. An author keyword analysis for mapping sport sciences, PLoS One, Vol. 13, No. 8, e0201435, 2018. https://doi.org/10.1371/journal.pone.0201435.

[47] M. Tomanek, A. Lis. Managing information on the physical education research field: Bibliometric analysis, Physical Education of Students, Vol. 24, No. 4, 213-226, 2020. https://doi.org/10.15561/20755279.2020.0404.

[48] J. Y. Cagas, M. Hassandra. The basic psychological needs in physical education scale in Filipino: An exploratory factor analysis, Philippine Journal of Psychology, Vol. 47, No. (1), 19-40, 2014. https://jyx.jyu.fi/bitstream/handle/12 3456789/58919/pjp2014-47-1-pp19-40-cagashassandra-the _basic_psychological_needs_in_physical_education.pdf?s $\overline{\text { equence }}=3 \&$ is Allowed $=\mathrm{y}$.

[49] B. Liad. Impact of Physical Education related activities in the holistic development of students in state universities and colleges in Northern Philippines, Journal of Critical Reviews, Vol. 7, No. 11, 1841-1864, 2020. http://www.jcreview.com/?mno=101184.

[50] M. A. Garcia, M. T. Bojos, G. U. Sy. Potential factors in engaging physical activity beyond Physical Education class, European Journal of Physical Education and Sports Science, Vol. 6, No. 10, 90-100, 2021. http://dx.doi.org/10.46827/ej pe.v6i10.3571.

[51] J. C. G. Tolentino, J. P. P. Miranda, V. G. M. Maniago, V. B.
Sibug. Development and evaluation of localized digital learning modules for indigenous peoples' health education in the Philippines, Universal Journal of Educational Research, Vol. 8, No. 12, 6853-6862, 2020. http://doi.org/10.13189/ujer.2020.081251.

[52] D. Pestano. Sports teachers coaching style behavior competency and student athletes performance in sports, Kinestetik: Jurnal Ilmiah Pendidikan Jasmani, Vol. 5, No. 1, 9-16, 2021. https://doi.org/10.33369/jk.v5il.14619.

[53] A. N. Endozo. Current exercise habits and factors affecting physical activity participation among university students, Global Journal of Health Science, Vol. 11, No. 4, 117, 2019. https://ideas.repec.org/a/ibn/gjhsjl/v11y2019i4p117.html.

[54] D. C. Panganiban. Quality assessment of physical education program of state universities in the Philippines, Jurnal SPORTIF: Jurnal Penelitian Pembelajaran, Vol. 5, No. 2, 166-174, 2019. https://doi.org/10.29407/js_unpgri.v5i2.12 983.

[55] G. C. Cobar, M. C. B. Borromeo, J. K. M. Agcaoili, A. M. T. Rodil. Acute effect of birdwatching on mood states of senior high school students in the physical education setting, Ovidius University Annals, Series Physical Education \& Sport/Science, Movement \& Health, Vol. 17, No. 1, 2017.

[56] E. O. Estrella. Adapted physical education program for handicapped students among state universities and colleges in Region 1 of the Philippines, Asian Journal of Multidisciplinary Studies, Vol. 3, No. 1, 17-27, 2020. https://asianjournal.org/online/index.php/ajms/article/view/ 195/91.

[57] S. Pituk, J. Y. Cagas. Physical activity and physical fitness among Filipino university students, Journal of Physical Education, Vol. 30, 1-10, 2019. https://www.scielo.br/j/jpe /a/FBx5DfP8RQFrmsHkVjkpwYg/?lang=en\#.

[58] A. Abbasi, L. Hossain, C. Owen. Exploring the relationship between research impact and collaborations for Information Science, 2012 45th Hawaii International Conference on System Sciences, 2012. https://doi:10.1109/hicss.2012.664.

[59] S. Kyvik, I. Reymert. Research collaboration in groups and networks: Differences across academic fields, Scientometrics, Vol. 133, 951-967, 2017.https://doi.org/10 $.1007 / \mathrm{s} 11192-017-2497-5$.

[60] L. Aldieri, M. Kotsemir, C. P. Vinci. The impact of research collaboration on academic performance: An empirical analysis for some European countries, Socio-Economic Planning Sciences, Vol. 62, 13-30, 2018. https://doi:10.10 16/j.seps.2017.05.003.

[61] E. Y. Li, C. H. Liao, H. R. Yen. Co-authorship networks and research impact: A social capital perspective, Research Policy, Vol. 42, No. (9), 1515-1530, 2013. https://doi:10.1016/j.respol.2013.06.012 